\begin{tabular}{|c|c|c|c|}
\hline \multirow{2}{*}{$\begin{array}{c}\text { LARUS } \\
\text { Hrvatska akademija } \\
\text { znanosti i umjetnosti }\end{array}$} & 53 & $\begin{array}{c}19-31 \text { str. } \\
3 \text { slike }\end{array}$ & Zagreb 2018 \\
\cline { 2 - 4 } & $(2018)$ & \multicolumn{3}{|c|}{$\begin{array}{c}\text { Primljeno 21.6.2018. } \\
\end{array}$} & Prihvaćeno na sjednici Razreda za prirodne znanosti HAZU 9.10.2018. \\
\hline
\end{tabular}

UDK 598.278.1(497.5)

Original scientific paper

\title{
EUROPEAN ROLLER Coracias garrulus IN CROATIA: HISTORICAL REVIEW, CURRENT STATUS AND FUTURE PERSPECTIVE
}

\section{Zlatovrana Coracias garrulus u Hrvatskoj: povijesni pregled, sadašnji status te budući izgledi}

\section{Sanja Barišić, Vesna Tutiš, Davor Ćiković, Jelena Kralj}

Institute of Ornithology, Croatian Academy of Sciences and Arts, Gundulićeva 24, HR-1000 Zagreb, Croatia

\begin{abstract}
Historical records of occurrence of the European Roller Coracias garrulus in Croatia are examined to determine its former breeding distribution in Croatia. The European Roller once bred in lowland region of Croatia and was most numerous in river valleys. As in most other parts of its European breeding range, it suffered a severe decline and finally went extinct in lowland region. The last confirmation of its breeding in lowland region was from Hrvatsko Zagorje from the 1980s. At the same time, in the 1980s, breeding was for the first time recorded in the coastal region, in Ravni kotari. After almost thirty years without confirmations, breeding was again confirmed in Ravni kotari in 2010. Following the rediscovery, a monitoring program was initiated in 2011. Subsequently, breeding attempt was also recoreded in Istria. Launching targeted conservation measures is urgently needed to preserve the European Roller as a breeding bird in Croatia.
\end{abstract}

Keywords: breeding population, lowland Croatia, Ravni kotari, Istria, threats

\section{INTRODUCTION}

The European Roller Coracias garrulus (hereafter Roller) is a long-distance migratory bird. It breeds throughout temperate, steppe and Mediterranean zones

e-mail: sbarisic@hazu.hr, vtutis@hazu.hr, cikovicd@hazu.hr, jkralj@hazu.hr 
characterized by reliable warm summer climates and winters in Afrotropical region (CRAmp \& Simmons 2006). It is an obligate secondary cavity-nesting bird dependent on a supply of large nesting cavities, in Europe mostly in white poplar Populus alba (BirdLife International 2017). Their diet is mainly insectivorous, largely consisted of medium- to large-sized beetles and crickets (CRAmp \& SimMONs 2006), and they mostly forage in agricultural habitats, especially meadows and cereals with fallow lands where hedges (as well as powerlines) are essential component of habitat as foraging perches (BirdLife InTERnAtional 2017). The Roller was once widely distributed throughout Europe and Asia. In the second half of the $19^{\text {th }}$ century, mostly during 1970-1990, it suffered a dramatic decline and local extinctions in Europe, most likely connected to the changes in abundances of prey and natural nesting cavities. Consequently, nesting opportunities have been reduced and breeding success depressed (TucKer \& HeATH 1994). The species decline in Europe coincided with the transformation of agricultural practices, most notable so in western and northern Europe. Modernisation and intensification of agricultural production brought about the conversion of pastures to arable lands, traditional arable land into monoculture, as well as intensified use of pesticides and removal of hedges and trees. All these presumably had a significant influence on Roller's nesting opportunities and breeding success (BirdLife InTERnAtionAL 2017). The Roller's decline has also been partly attributed to climatic change. For example, Durango (1946) attributes the population decline and extinction in Sweden to climatic change, mostly emphasising the negative impact of elevated precipitation levels. An additional significant threat is persecution during migration in some Mediterranean countries, where hundreds, perhaps thousands are killed each year (Fry et al. 2017). The most recent assessment of the European population suggests that the decline has slowed (BirdLife International 2017) and consequently the species has been globally down-listed to a Least Concern (LC) category. Although the population is still moderately declining, conservation actions in several countries have contributed to national recoveries. For example, after steep declines in the 1990s, the population in Hungary greatly recovered following nest-box provisioning (KIss et al. 2014). In Croatia, however, the species is still listed as Critically Endangered (BARišrć \& Tutiš 2013).

The aim of this paper was two-folded: to summarise all available information regarding Roller occurrence in Croatia in order to facilitate understanding of the patterns of historical change in Roller populations on a larger scale, and to assess the current status and vulnerability, as well as the risk factors affecting the survival of the species in Croatia.

\section{MATERIALS AND METHODS}

Data concerning the historical occurrence of the Roller in Croatia were obtained from: the national Zagreb ringing scheme database, museum collections 
(Gjetvaj 1988, Sušić et al. 1988, Piasevoli \& Pallaoro 1991, Rucner 1993, Kralj \& Tutiš 1996, Lukač \& Baltić 2001, Grbac \& Kralj 2008), reports of the Croatian Ornithological Centre (Rössler 1901-1923, Plančić 1925, 1926) and other publications. An extensive search of published literature was performed, and 140 references that contained information regarding the Roller occurrence in Croatia were found.

All ringed birds, except one, were ringed as nestlings thus were treated as confirmed breeding records. Data from published literature were assigned as cofirmed breeding records if the Roller was listed or described as a breeding species by the source author. Data from museum collections and published literature were treated as probable breeding records if the birds were observed from the second half of June until the beginning of August, in the period when birds on migration are less likely to occur. The only fledgling specimen in museum collections was assigned as a confirmed breeding record.

The oldest reference concerning Roller occurrence in Croatia is from the $19^{\text {th }}$ century (SEIDENSACHer 1863), but only after the establishment of Croatian Ornithological Centre in 1901 has Roller occurrence during migration been regularly recorded, up until 1924 when organised monitoring of bird migration in Croatia ceased (Rössler 1901-1923, Plančić 1925, 1926). In total, 1001 migration observations were extracted, out of which $90 \%$ were from the 1901-1924 period.

Information concerning the recent distribution of breeding population and the status of the Roller in Croatia are based on a monitoring program conducted by the authors (Tuтıš et al. 2011, 2012, 2013, 2014, unpublished data 2015-2017). The monitoring program focuses on the areas with recently confirmed breeding records. These areas are visited several times in the breeding season, between early May and late July, in order to map all breeding territories, confirm breeding at each territory, locate the position of nest-holes and determine the breeding success. Nest-boxes have been provided and monitored for occupancy and the breeding success since 2013. Furthermore, all other Roller observations that were publicly available (citizen-based bird observation networks) or that were personally communicated by the community (ornithologists, bird watchers, bird ringers, etc.) were evaluated or checked as possible records of breeding.

Occurrence sites were divided into lowland, mountainous and coastal (Istria, Primorje and Dalmatia) regions of Croatia (Figure 1). 


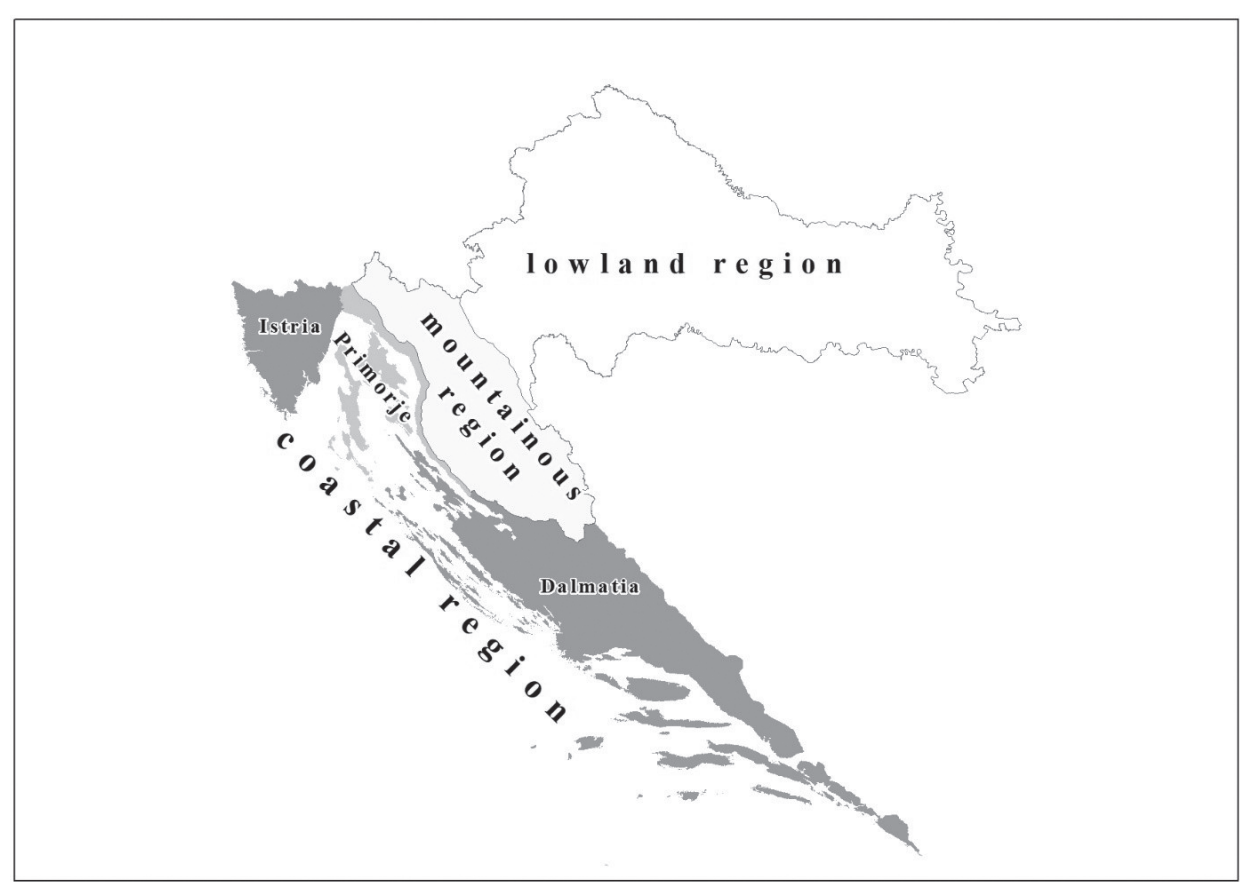

Figure 1. Regions in Croatia (lowland and mountainous regions are shown in white, coastal region with its subregions is shown in shades of grey).

Slika 1. Regije u Hrvatskoj (nizinska i planinska regija prikazane su bijelo, a primorska regija s podregijama nijansama sive).

\section{RESULTS AND DISCUSSION}

\section{Historical records in the breeding season}

Historically in Croatia Rollers were only recorded breeding in the lowland region, where breeding records span from 1870s till 1980s, whereas breeding in the coastal region was not confirmed up to the 1980 s.

The first five Rollers ringed with Zagreb ringing scheme rings were ringed in 1914. However, details on ringing location are missing, and it's possible that these birds were ringed outside Croatia as Zagreb ringing scheme previously coordinated ringing across the former Yugoslavia (apart from Slovenia). Since 1939, a total of 143 Rollers have been ringed in Croatia with the last bird ringed in 1967. All these birds were ringed as nestlings apart from one bird that was ringed as a juvenile, and all were ringed in the lowland region. Most of these birds were ringed in the Mura river valley (Međimurje, Figure 2) by Andrija Lesinger from 1955-1959 (138 nestlings). The earliest ringing date of nestlings was $1^{\text {st }}$ of June in 1958 which is extraordinarily early given that the species mostly starts laying from the beginning of May (CRAmp \& Simmons 2006). 


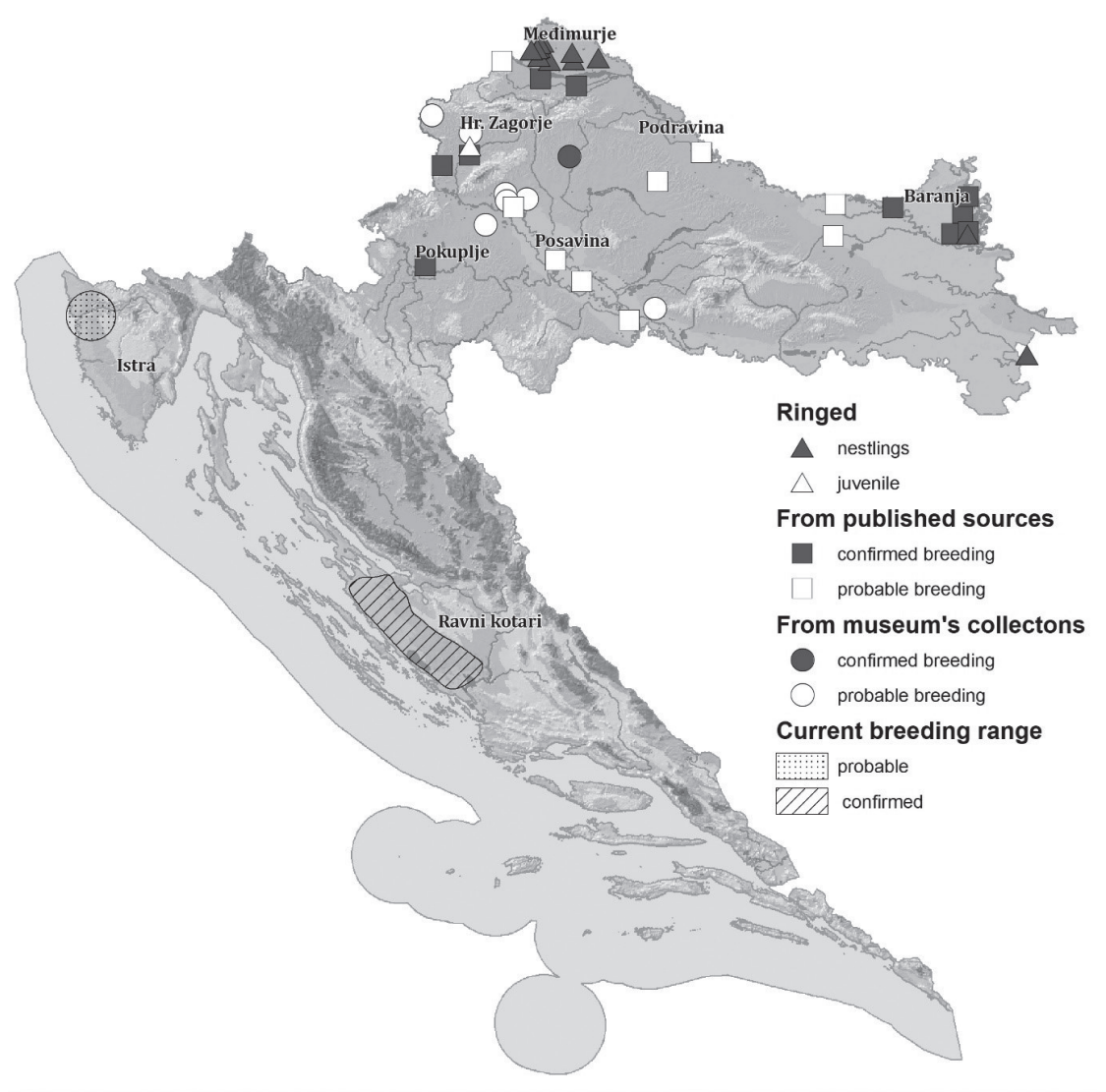

Figure 2. Localities of the historical breeding records (confirmed and probable) of the European Roller in Croatia and the current breeding range with relevant geographic microregions in Croatia denoted.

Slika 2. Povijesna mjesta gniježđenja zlatovrane (potvrđena i vjerojatna) u Hrvatskoj te sadašnji gnijezdeći areal s naznačenim relevantnim mikroregijama Hrvatske.

Various scientific bird collections represent valuable data about the occurrence of Rollers in Croatia. All the specimens that were collected during the breeding season were from the lowland region. Collection of bird skins from the Institute of Ornithology of the Croatian Academy of Sciences and Arts holds 13 skins, four of which are from the breeding season (from Sesvete and Ivanja Reka in 1948, and two from Stara Ves Ravenska in 1963 including one fledgling). The bird collection of the Croatian Natural History Museum holds 19 bird skins or mounts, 14 of which can be assigned to Croatia with certainty. Five of these were collected during the breeding season (from Dugo Selo 1874, Novska 1904, Lukavec 1932, Trnovec 1934, and Začretje 1946). All other bird collections hold specimens collected outside the breeding season. 
Information concerning the Croatian breeding population found in other published literature is somewhat scarce and usually lack details concerning localities and abundance. All records referring to breeding birds originate from lowland region and most are from river valleys (Figure 2). It is likely that the Roller was most numerous in riverine habitats, possibly due to availabilities of nesting cavities.

Several references list the Roller as a breeding bird in Baranja (Figure 2) (Mikuska \& Majıć 1970, Mikuska 1981, Mikuska \& Mikuska 1994). In Bilje surroundings, Mojsisovics (1883) described the Roller as a frequent breeding bird. RUCNER \& RUCNER (1972), while surveying birds in Baranja region in 1966, recorded two pairs along a 7.5-km-long transect in poplar forest (Populus alba) adjacent to Drava river and one pair along the 4-km-long transect in oak forest (Quercus robur) adjacent to Kopački rit. It was also recorded breeding near Tikveš castle (Mıкuska 1979).

In the Drava river valley (Podravina, Figure 2), it was recorded as a common breeding bird at the beginning of $20^{\text {th }}$ century (HirTz 1908), with only one record from the breeding season mentioning a locality - near Pitomača in 1912 (RössLER 1913). It was described as a well-known but rare breeder in Varaždin surroundings at the end of $19^{\text {th }}$ century (JURINAC 1884).

In Hrvatsko Zagorje (Figure 2), breeding was recorded between 1961 and 1963 in oak forest near village Rozga adjacent to Sutla river (RUCNER 1967, RUCNER \& RuCNer 1971) and near village Mokrice (Dolenec 2003).

In the breeding season, it was recorded in the Sava river valley (Posavina, Figure 2): in 1909 near village Krapje (Rössler 1910), in 1957 just downstream of Zagreb (SCHNeIder 1989), in 1968 near village Svinjičko (Rucner 1970), and in 1987 near village Setuš (ERN 1960).

In the Kupa river valley (Pokuplje, Figure 2), it was recorded breeding near Draganići fishponds in 1960 (IgALFFy 1964).

Historically in the coastal region Rollers were not confirmed breeding. In Dalmatia, all historical records, including the records from museum collections, originated outside the breeding season. Breeding in Primorje and Istria was not confirmed as well, even though birds were observed during the breeding season, near village Hreljin in 2006, near Matulji in 1885, and in the National Park Brijuni in 1993 (Washington 1885, Mužinić \& Ende 2006, Lukač \& Stelko 2016).

\section{Non-breeding records}

In the non-breeding periods, Rollers were recorded, mostly singly, throughout the whole of Croatia. Based on skin collections, the earliest confirmed date of spring migration is $31^{\text {st }}$ of March (GJETVAJ, B.) while the latest confirmed date of autumn migration is $24^{\text {th }}$ of September (LuKač \& BALtić 2001). In the coastal region, it was observed more often during the spring migration than in the autumn 
(Kolombatović 1880, Maštrović 1931). Several authors note that the species is becoming rarer (Tschusi zu Schmidhoffen 1889, Krpan 1980, Tutman 1980) and that it is often shot by local people (Tutman 1952, 1980). It was recorded on several Adriatic islands: Krk (Rucner 1998), Cres (Goran Sušrć, pers. comm.), Rab (Ash 1970), Pag (Bordjan 2006), Hvar (Schiebel 1908), Vis (Krpan 1965), Lapad (Tutman 1954, 1980), Lokrum (Rudolf von Habsburg 1887, Tutman 1980), and even on the small remote island of Palagruža in the middle of the Adriatic Sea (Godez 1898); demonstrating that Rollers fly over the Adriatic Sea in a broad front. It was regularly observed migrating through the lowlands (Mojsisovics 1883, Hirtz 1913) and even in the mountainous region (Rössler 1908, ANONYMOUS 1947, RUCNER 1958).

An assessment of migration phenology of Rollers in Croatia (Figure 3) is based on migration dates that were mainly obtained from the monitoring of bird migration through Croatia organised from 1901 till 1924 (Rössler 1901-1923, PlanČić 1925, 1926) and other published literature. Overall, the Roller was observed more often during the spring migration than in the autumn. Even though the start of spring migration was recorded as early as the beginning of March and the last Rollers in autumn were recorded in first decade of November, most of these early and late records can be attributed to erroneous observations. During spring migration most of the birds move through Croatia in the last decade of April while the late birds were still observed in the second half of May. The autumn migration starts as early as the beginning of August and ends at the end of October. Compared to spring migration, peak in the passage during autumn migration is less pronounced with the majority of birds migrating throughout September. According to RUCNER (1998), the Roller migrates through the coastal region in the second half of April and throughout May and from the end of August through the first half of September.

\section{Recent distribution and status of the breeding population}

The Roller is currently treated as extinct in lowland region. The last confirmation of breeding in lowland region dates from the 1980s from Hrvatsko Zagorje (Dolenec 2003).

In the same decade, breeding was for the first time recorded in the coastal region, but only in Ravni kotari (northern Dalmatia) (Eduard KLETEČKI, KrešImir Leskovar pers. comm.). After the initial confirmation of breeding in Ravni kotari, Rollers were not observed there until 2010 when two breeding pairs were accidently discovered. Surveying of the Roller distribution and monitoring of the population size and breeding success was initiated in 2011. Since then, Rollers were confirmed breeding in several localities in Ravni kotari with the population size estimated at 15-20 pairs in 2017. Most of the localities where Rollers are currently breeding are remains of former marshlands that have been drained 
and transformed into fertile agricultural fields and grasslands (HeKMAN 1971). To protect the soil from wind erosion, poplar trees (mostly of a hybrid Populus $x$ canadensis, TomAšEvić 1996) were commonly planted in hedgerows along excavated canals as windbreaks, forming a grid of trees. Transformation of marshes into pastures provided suitable forging grounds while poplars provided nesting cavities. These two agri-environmental interventions appear to be crucial in providing the nesting opportunities for Rollers in Ravni kotari.

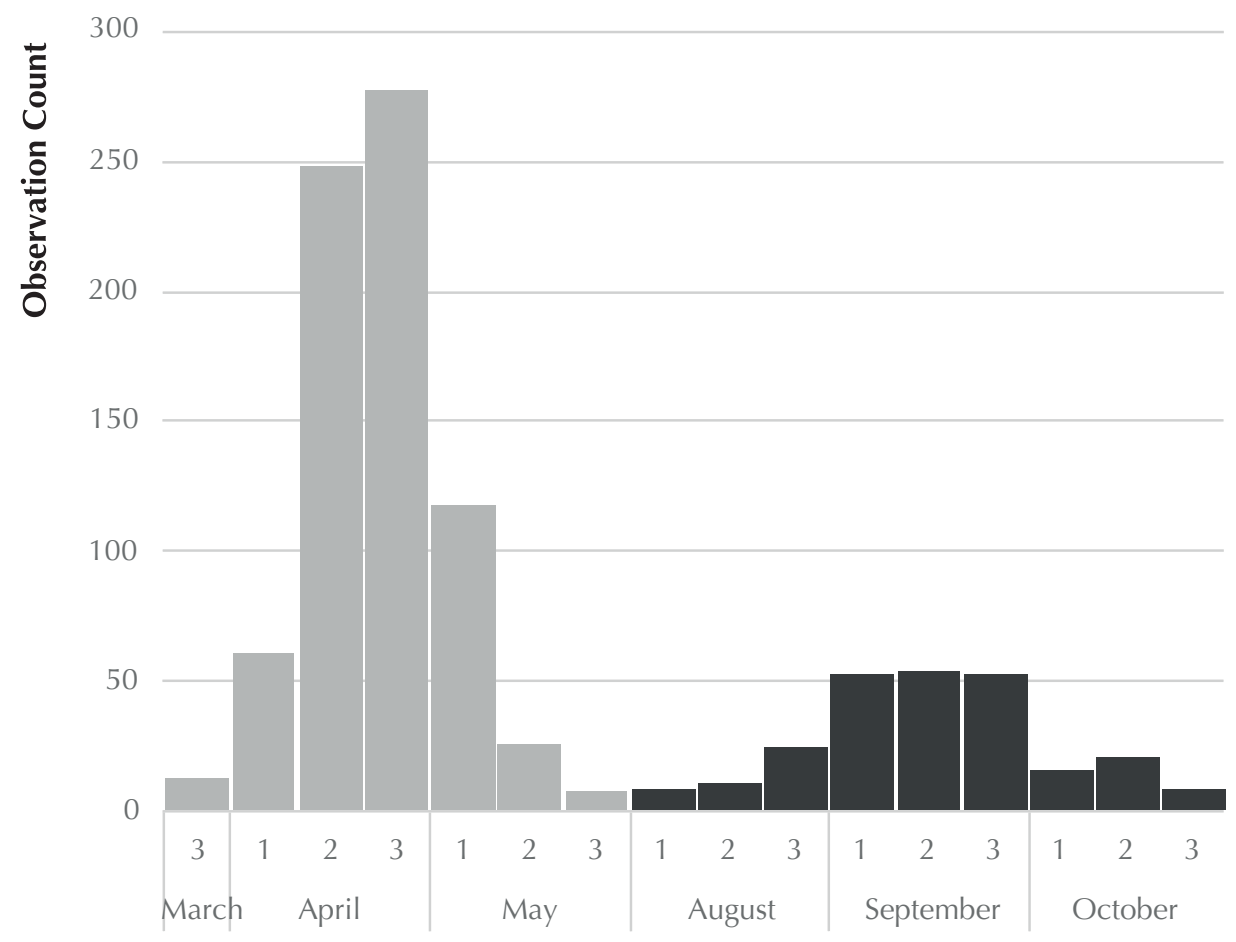

Figure 3. Phenology of the Roller migration in Croatia based on monitoring of bird migration through Croatia during 1901-1924 (90\% of records) and migration dates found in other published literature.

Slika 3. Fenologija selidbe zlatovrane kroz Hrvatsku koja se temelji na praćenju selidbe ptica kroz Hrvatsku tijekom 1901-1924 (90\% podataka) te ostalih datuma selidbe dostupnih u literaturi.

Breeding attempt was recorded in Istria, in the river Mirna valley, in 2016 (MARко MAтEšIć, pers. comm.). One pair was observed entering a cavity in poplar snag, but successful breeding was not confirmed. Unfortunately, afterwards the snag was removed during a watercourse management and in 2017 breed- 
ing was not confirmed, even though Rollers were observed in the area (RoвERTo STELKO, pers. comm.). This area is approximately $200 \mathrm{~km}$ away from Ravni kotari. However, it is represented by similar habitats - pastures and arable fields with poplars adjacent to the river Mirna.

Currently, several factors are elevating the risk of population decline and even extinction of the Roller in Croatia. Poplars, the primary nesting substrate for the Roller, were planted during the mid- $20^{\text {th }}$ century and now most of the trees are in the decaying phase. The decline of poplars is accelerated by illegal fires frequently used to clear the undergrowth around the trees. Even though poplars naturally rejuvenate, most of the saplings are destroyed by canal management and fires. Also, the existing irrigation plan of Zadar County (Romić 2007) mainly focuses on the areas where Rollers breed. According to this plan, fields that are now mainly used as grasslands or for cereal production are planned to be transformed into irrigated fields with orchard, olive groves and vineyards or for intensive vegetable production, presenting unsuitable or suboptimal habitats for the Roller. Even though most of the Rollers breeding territories are inside borders of the Natura 2000 site Ravni kotari (HR1000024), plans to preserve suitable habitats for the Roller are still not developed. Furthermore, the illegal killing of Rollers can still be considered as a significant threat. In 2013, a bird was found shot beneath the tree where it was nesting. In the same year, the remains of two more adults were found, although post-mortem examinations were inconclusive. Apart from the factors mentioned above, the small size of the current breeding population further increases its vulnerability. To preserve the Roller as a breeding bird in Croatia an urgent initiation of targeted conservation measures is of uttermost importance. Furthermore, all current rural development plans should be re-evaluated taking into account conservation of Roller and other target species of Natura2000 site Ravni kotari (HR1000024).

\section{Acknowledgements}

We thank Ivan Dević and Ivan Darko Grlica for participating in the Roller monitoring program. We are grateful to Bernard Wiesner, Michael Tiefenbach, Ivan Darko Grlica and Ivan Dević for providing and installing the nestboxes for Rollers. We would also like to thank Public Institutions for the management of protected natural values of Zadar county (Natura Jadera), Šibenik-Knin county (Priroda) and Istria county (Nutura Histrica) for providing the nestboxes for Rollers and providing the support for installing them. Finally, we thank Emilio Menđušić for conducting a post-mortem examination of Roller carcases. Survey of the Roller distribution and monitoring of the population size in the Natura 2000 site Ravni kotari was partly financed by the Croatian Agency for Environment and Nature. 


\section{References}

Anonymous (1947): Modra zlatovrana u Gorskom Kotaru. Priroda 34: 194.

Ash, J.S. (1970): Observations from Rab, Autumn 1966. Larus 21-22: 121-129.

Barišić, S., Tutiš, V. (2013): Zlatovrana Coracias garrulus. pp. 118-120 In: Tutiš, V., Kralu, J., Radović, D., Ćı́ović, D., BARIšıć, S. (eds.): Crvena knjiga ptica Hrvatske. Ministarstvo zaštite okoliša i prirode, Državni zavod za zaštitu prirode, Zagreb.

BirdLife International (2017): Species factsheet: Coracias garrulus. Downloaded from http://www.birdlife.org on 8 November 2017.

BordjAn, D. (2006): From the ornithological notebook: European Roller Coracias garrulus. Acrocephalus 27: 99-113.

Cramp, S., Simmons K.e.L. (eds.) (2006): BWPi 2.0.1. Birds of the Western Palearctic interactive (DVD-ROM). BirdGuides Ltd. Sheffield.

Dolenec, Z. (2003): Qualitative structure of the community of nesting birds between 19712000 in the Mokrice rural area (NW Croatia). Nat. Croat. 12: 121-130.

Durango, S. (1946): Blåkråkan (Coracias g. garrulus L.) i Sverige. Vår Fågelvärld 5: 145-190.

ERN, H. (1960): Ornithologische Beobachtungen während einer Wanderung durch Jugoslawien. Larus 12-13: 107-121.

Fry, H., Boesman, P., Kirwan, G.M., Sharpe, C.J. (2017): European Roller (Coracias garrulus). In: del Hoyo, J., Elliott, A., Sargatal, J., Christie, D.A., de Juana, E. (eds.): Handbook of the Birds of the World Alive. Lynx Edicions. Barcelona. Downloaded from https://www.hbw.com on 8 November 2017.

GJETvaJ, B. (1988): Zbirka ptica lovačkog društva 'Jarebica' - Bale (Istra). Larus 38-39: 165-177.

Godez, A. (1898): Beobachtungen über den Vogelzug auf der Insel Pelagosa im Adriatischen Meere,angestellt vom 27. September bis 8. November 1897. Mitt. Orn. Ver. Wien (Die Schwalbe) 1: 115-127.

Grbac, I., Kralj, J. (2008): Katalog Zbirke ptica Hrvatskog prirodoslovnog muzeja. Natura Croatica 17: 1-226.

Некмал, F. (1971): Melioracija Vranskog jezera: vodoprivredna problematika Vranskog područja. Acta Instituti Academiae jugoslavicae scientiarium er artium in Zadar 18: 469-476.

Hirtz, M. (1908): Die Jagdfauna der Domäne Martijanec. Zagreb.

Hirtz, M. (1913): Kritische Bemerkungen zur Monographie: Madarasz, Die Vögel Ungarns. Glas. Hrv. prir. društva 25: 184-193., 26: 8-22., 65-74., 129-144., 197-206., 27: 7-23.

IGALffy, K. (1964): Prilog fauni ptica ribnjaka Draganići i okolice. Zbornik Gradskog muzeja Karlovac 1: 256-272.

JurinAC, A.E. (1884): Kičmenjaci okolice Varaždinske. Izvješće Kralj. velike gimnazije u Varaždinu koncem šk. god. 1883 4: 1-60.

KIss, O., Elek, Z., Moskát, C. (2014): High breeding performance of European Rollers Coracias garrulus in heterogeneous farmland habitat in southern Hungary. Bird Study 61: 496-505. 
Kolombatović, G. (1880): Osservazioni sugli uccelli della Dalmazia. Split.

KralJ, J., Tutiš, V. (1996): Samples of Birds from Croatia in the Ornithological Collection of the Natural History Museum in Vienna. Nat. Croat. 5: 25-51.

Krpan, M. (1965): Ptice otoka Visa i njemu bližih otočića. Larus 16-18: 106-150.

KRPAN, M. (1980): Srednjodalmatinska ornitofauna. Larus 31-32: 97-156.

Lukač, G., Baltić, M. (2001): Diversity and richness of the Ornithological collection of the wider Dubrovnik area (Croatia). Nat. Croat. 10: 321-365.

Lukač, G., Stelko, R. (2016): Atlas ptica Istre. Javna ustanova Natura Histrica. Pula.

Maštrović, A. (1931): Prilog avifauni sjeverne Dalmacije. Lov.-rib. vjesnik 40: 102-108, 247-255, 343-352, 387-391, 428-431.

Mıкuska, J. (1979): Ekološke osobine i zaštita Specijalnog zoološkog rezervata 'Kopački rit' s posebnim osvrtom na ekologiju kralješnjaka. Doctoral Thesis. Zagreb.

MıкUSKA, J. (1981): Fauna kralješnjaka specijalnog zoološkog rezervata 'Kopački rit' i okoline u Baranji. Biosistematika 7: 67-80.

Mikuska, J., Majıć, J. (1970): Ptice Baranje. Jelen 44: 37-47.

Mıкuska, J., Mıкuska, T. (1994): Ptice Dunava na području Hrvatske. Anali Zavoda za znanstveni rad u Osijeku 10: 109-175.

Mojsisovics, A. (1883): Zur Fauna von Bellye und Darda. Mitt. Naturwiss. Ver. Steiermark 19: 103-194.

MužInIĆ, J., EndE, B. (2006): From the ornithological notebook: European roller Coracias garrulus. Acrocephalus 27: 99-114.

Piasevoli, G., Pallaoro, A. (1991): Ornitološka zbirka prirodoslovnog muzeja u Splitu. Larus 43: 89-119.

Plančić, J. (1925): Selenje ptica na teritoriji Hrvatske i Slavonije u 1921., 1922. i 1923 god. Zagreb.

Plančıć, J. (1926): Selenje ptica na teritoriju Hrvatske i Slavonije u godini 1924. Zagreb

Romić, D. (2007): Plan navodnjavanja za područje zadarske županije. Agronomski fakultet Sveučilišta u Zagrebu.

Rössler, E. (1902-1923): Annual report I-XX. Croatian Ornithological Centre. Zagreb.

Rössler, E. (1908): Selidba ptica u Hrvatskoj i Slavoniji god. 1907. Glas. Hrv. narav. društva 20: 1-95.

Rössler, E. (1910): Selidba ptica u Hrvatskoj i Slavoniji god. 1909. Glas. Hrv. narav. društva 22: 1-110.

Rössler, E. (1913): Selidba ptica u Hrvatskoj i Slavoniji god. 1912. Zagreb.

Rucner, D. (1958): Kratki osvrt na ornitofaunu Plitvičkih jezera. pp. 391-400. In: Šafar, J. (ed.): Nacionalni park Plitvička jezera. Zagreb.

Rucner, D. (1967): Prilog poznavanju ekološkog značenja ornitofaune okolice Klanjca (Hrvatsko Zagorje). Larus 19: 86-106.

Rucner, D. (1998): Ptice hrvatske obale Jadrana. Croatian Natural History Museum. Zagreb.

Rucner, D., Rucner, R. (1971): Prilog poznavanju faune nekih šumskih zajednica u Hrvatskoj. Larus 23: 129-203. 
Rucner, D., Rucner, R. (1972): Prilog poznavanju napučenosti ptica u biotopima Baranje. Larus 24: 31-64.

Rucner, R. (1970): Prilog poznavanju ptičjeg svijeta Lonjskog polja. Larus 21-22: 31-64.

Rucner, D. (1993): O životu ptica u dolini Neretve. Ogranak Matice Hrvatske u Metkoviću. Klek, Metković.

Rudolf von Habsburg (1887): Ornitoložke bilježke s juga. Glas. Hrv. narav. društva 2: 3-16.

Schiebel, G. (1908): Beiträge zur Ornithologie der süddalmatinischen Insel Lesina (nebst anderen Reisenotizen). II. Orn. Jahrbuch. 1-2: 1-30.

SchneIder, M. (1989): Endangered and rare birds in the alluvial wetlands of the Sava river on the Posavina/Croatia. Larus 40: 167-178.

Seidensacher, E. (1863): Einige ornithologische Beobachtungen in Croatien. Verh. zoolbot. Gesel. Wien 13: 1137-1148.

Sušić, G., RAdović, D., BARTovsky, V. (1988): Znanstvena zbirka ptičjih svlakova Zavoda za ornitologiju JAZU. pp. 37-88. In: Mešrrov M., Sušı́́ G. (eds.): Ornitologija u Hrvatskoj. Jugoslavenska akademija znanosti i umjetnosti. Zagreb.

TomAšEvić, A. (1996): Vjetrozaštita Sinjskog polja. Šumarski list 1-2: 19-34.

Tschusi zu Schmidhoffen, V., Dalla-Torre, K. (1889): Sechster Jahresbericht (1887) des Comité's für ornithologische Beobachtungsstationen in Oesterreich-Ungarn. Ornis 6: 201-286.

Tucker, G.M., Heath, M.F. (1994): Birds in Europe: their conservation status. BirdLife International. Cambridge.

Tutiš, V., BARIŠıć, S., Ćiković, D., KRALJ, J. (2011): Brojnost, rasprostranjenost i staništa zlatovrane (Coracias garrulus) na području Ravnih kotara - 1. godina istraživanja. Zavod za ornitologiju HAZU. Zagreb.

TutIŠ, V., BARIšIĆ, S., Ćiković, D., KRALJ, J. (2012): Istraživanje brojnosti i rasprostranjenosti zlatovrane Coracias garrulus na području Ravnih kotara - 2. godina. Zavod za ornitologiju HAZU. Zagreb.

Tutiš, V., BARIšIĆ, S., Ćiković, D., KRALJ, J. (2013): Monitoring veličine populacije i uspješnosti gniježđenja zlatovrane Coracias garrulus na području Ravnih kotara u 2013. Zavod za ornitologiju HAZU. Zagreb.

Tutiš, V., BArišić, S., Ćiković, D., KRALJ, J. (2014): Monitoring veličine populacije zlatovrane (Coracias garrulus) na području Ravnih kotara u 2014. Zavod za ornitologiju HAZU. Zagreb.

Tutman, I. (1952): S ornitološkom bilježnicom kroz krajeve Dalmacije. Larus 4-5: 99-121.

TutMan, I. (1954): Iz ornitološkog dnevnika. II. dio. Larus 6-7: 144-176.

Tutman, I. (1980): Sastav i dinamika mješovitih populacija ptica dubrovačkog područja. Doctoral Thesis, Sarajevo.

Washington, S. (1885): Ornithologische Notizen aus Istrien. Zeit. Ges. Ornithol., 2: 341367. 


\section{SAŽETAK}

Pregledani su povijesni podaci o opažanjima zlatovrane Coracias garrulus u Hrvatskoj kako bi se utvrdio nekadašnji areal gniježđenja. Zlatovrana se u prošlosti gnijezdila diljem nizinske Hrvatske te je bila najbrojnija u dolinama rijeka. Slično kao i u ostatku gnijezdećeg areala u Europi, zlatovrana je u Hrvatskoj pretrpjela drastični pad populacije te je najzad u nizinskoj Hrvatskoj izumrla. Zadnji podaci o njenom gniježđenju u nizinskoj Hrvatskoj potječu iz 1980-ih godina. Istovremeno, po prvi puta je utvrđeno gniježđenje zlatovrane 1980-ih godina u priobalju, u Ravnim kotarima. Nakon približno trideset godina bez potvrde, gniježđenje zlatovrane je u Ravnim kotarima zabilježeno tek 2010. godine. Iduće godine pokrenut je program monitoringa u Ravnim kotarima te je pokušaj gniježđenja utvrđen i na području Istre. Kako bi se sačuvala gnijezdeća populacija zlatovrane u Hrvatskoj, potrebno je hitno započeti s provođenjem ciljanih mjera zaštite. 